\title{
DEVELOPMENT AND STANDARDISATION OF THE SENTENCE IDENTIFICATION TEST IN THE KANNADA LANGUAGE
}

\author{
Chinnaraj Geetha, Keelara Shivaraju Sharath Kumar, Puttabasappa Manjula, \\ Mahadevaiah Pavan
}

Department of Audiology, All India Institute of Speech and Hearing, Mysore, India

Corresponding author: Chinnaraj Geetha, Department of Audiology, All India Institute of Speech and Hearing, Mysore, India, e-mail: geethamysore.cs@gmail.com

\begin{abstract}
Background: The present study aimed to develop and standardise the sentence identification test in the Kannada language. This study used a normative research design that included development and standardisation of sentence tests.

Material and methods: A total of 700 sentences in the Kannada language, selected from various sources, were evaluated for naturalness, predictability, and equivalency by 33 participants. Sentences considered to be natural, low in predictability, and equivalent were used to construct 30 lists of 10 sentences each. Standardisation of the material and list equivalency were assessed on 100 listeners with normal hearing ability.

Results: Based on ratings of naturalness and predictability, 564 sentences were considered as highly natural and of low predictability. Of these, 316 were found to have equal difficulty based on a performance-SNR function and were used to construct 30 lists. Repeated measures ANOVA and Bonferroni post hoc tests revealed Lists 1, 3, 15, 16, and 30 to be significantly different from at least one of the other lists. After removing these lists, the mean identification score for the final 25 lists at $-5 \mathrm{~dB}$ SNR was $54 \%$.
\end{abstract}

Conclusions: The sentence identification test in Kannada for adults consists of 25 homogenous lists. The normative for the same is also given in the study. Its application is being assessed for hearing evaluation in the clinical population.

Keywords: sentence test $\bullet$ equivalent lists $\bullet$ Kannada language $\bullet$ standardisation

DESARROLLO Y ESTANDARIZACIÓN DEL TEXTO CON APLICACIÓN DE LISTADOS DE FRASES EN EL LENGUAJE KANNADA

\section{Resumen}

Introducción: El objetivo de este estudio ha sido el de desarrollar y estandarizar el texto con aplicación de listados de frases en el lenguaje kannada. Se ha basado en el proyecto normativo de estudios, que abarcaba el desarrollo y estandarización de textos con la aplicación de listados de frases.

Materiales y métodos: 33 participantes valoraron 700 frases en el lenguaje kannada, procedentes de varias fuentes, en cuanto a su naturalidad, la previsibilidad y la equivalencia. De las sentencias valoradas como naturales, imprevisibles y equivalentes se han creado 30 listados, cada una de 10 frases. La estandarización de la equivalencia de los materiales y de listados ha sido valorada por 100 oyentes con capacidad auditiva correcta.

Resultados: Basándose en la valoración de la naturalidad y de la previsibilidad, 564 sentencias han sido consideradas como muy naturales e imprevisibles. Entre estas, 316 frases de igual grado de dificultad, basándose en la función de rendimiento SNR se ha utilizado para crear 30 listados. El análisis de variantes con mediciones repetidas (Repeated measures ANOVA) y las pruebas post hoc de Bonferroni, han demostrado que los listados 1, 3, 15, 16 y 30 difieren de forma considerable al menos de uno de los demás listados. Después de la eliminación de dichos listados, el resultado medio de reconocimiento para los 25 listados restantes en la escala de $5 \mathrm{~dB}$ SNR ha sido de $54 \%$.

Conclusiones: La prueba de reconocimiento de las frases en el lenguaje kannada para adultos consiste en 25 listados homogéneos. En el estudio se han presentado también los datos normativos. También se estudia la posibilidad de su aplicación a la hora de comprobar el oído de pacientes clínicos.

Palabras clave: prueba con la aplicación de listados de frases • listados de equivalencia • lenguaje kannada • estandarización 


\section{РАЗВИТИЕ И СТАНДАРТИЗАЦИЯ ТЕСТА С ИСПОЛЬЗОВАНИЕМ СПИСКА ПРЕДЛОЖЕНИЙ НА ЯЗЫКЕ КАННАДА}

\section{Изложение}

Введение: Цель настоящей работы - разработка и стандартизация теста с использованием списка предложений на языке Каннада. Базировано на нормативном проекте исследований, который включал в себя развитие и стандартизацию тестов с использованием списков предложений.

Материалы и методы: 33 участника оценило 700 предложений на языке каннада, происходящих из разных источников, в отношении естественности, предсказуемости и эквивалентности. Из предложений, оцененных как естественные, непредсказуемые и эквивалентные созданы 30 пар, по 10 предложений каждая. Стандартизация эквивалентности материалов и списков была оценена 100 слушателями с хорошим слухом.

Результаты: На основании оценки естественности и предсказуемости, 564 предложения были признаны очень естественными и непредсказуемыми. Среди них, 316 предложений с одинаковой степенью трудности на основании функции эффективности SNR использовано для создания 30 списков. Анализ вариантности с повторяемыми измерениями (Repeated measures ANOVA) и пост-хок тесты Бонферрони показали, что списки 1, 3, 15, 16 и 30 значительно отличаются, по крайней мере, от одного из остальных списков. После удаления этих списков, средний результат распознавания для остальных 25 списков в диапазоне 5 дБ SNR составил $54 \%$.

Итоги: Тест распознавания предложений на языке Каннада для взрослых состоит из 25 однородных списков. В работе представлены также нормативные данные. Исследуется также возможность его использования при оценке слуха у клинических пациентов.

Ключевые слова: тест с использованием списков предложений • эквивалентные списки • язык Каннада • стандартизация

\section{ROZWÓJ I STANDARYZACJA TESTU Z WYKORZYSTANIEM LIST ZDANIOWYCH W JEZZYKU KANNADA}

\section{Streszczenie}

Wprowadzenie: Celem niniejszej pracy było opracowanie i standaryzacja testu z wykorzystaniem list zdaniowych w języku kannada. Bazowano na normatywnym projekcie badań, który obejmował rozwój i standaryzację testów z wykorzystaniem list zdaniowych.

Materiały i metody: 33 uczestników oceniło 700 zdań w języku kannada, pochodzących z różnych źródeł, pod względem naturalności, przewidywalności i ekwiwalencji. Ze zdań ocenionych jako naturalne, nieprzewidywalne i ekwiwalentne stworzono 30 list, po 10 zdań każda. Standaryzacja ekwiwalencji materiałów i list była oceniona przez 100 słuchaczy z prawidłowym słuchem.

Wyniki: Na podstawie oceny naturalności i przewidywalności, 564 zdania zostały uznane za bardzo naturalne i nieprzewidywalne. Spośród nich, 316 zdań o równym stopniu trudności w oparciu o funkcję wydajności SNR użyto do stworzenia 30 list. Analiza wariancji z powtarzanymi pomiarami (Repeated measures ANOVA) i testy post hoc Bonferroniego wykazały, że listy 1, 3, 15, 16 i 30 są znacząco różne od co najmniej jednej z pozostałych list. Po usunięciu tych list, średni wynik rozpoznania dla pozostałych 25 list w skali 5 dB SNR wyniósł $54 \%$.

Wnioski: Test rozpoznawania zdań w języku kannada dla dorosłych składa się z 25 jednorodnych list. W pracy przedstawiono również dane normatywne. Bada się także możliwość jego wykorzystania przy ocenie słuchu u pacjentów klinicznych.

Słowa kluczowe: test z wykorzystaniem list zdaniowych • listy ekwiwalencyjne • język kannada • standaryzacja

\section{Background}

The measurement of speech perception provides useful information in assessing communication difficulties experienced by listeners with hearing impairment. The scope of speech perception tests extends to rehabilitation, particularly for the assessment and monitoring of an individual's speech perception ability before and after the fitting of hearing aids or cochlear implants [1]. Further, they help in choosing appropriate amplification and for counselling [2], providing a percentage score that is more easily understood by patients than the degree of hearing loss [3]. 
A variety of test materials such as nonsense syllables, monosyllables, bisyllables, and sentences are used to assess the speech perception abilities of individuals [4]. The most commonly used speech stimuli are monosyllabic or bisyllabic words and sentences. Bisyllables are preferred since every language does not have concrete monosyllabic words and bisyllables provide more cues for intelligibility than do monosyllables [5].

Carhart [6] preferred monosyllabic words owing to their non-redundancy and meaningfulness. He also stated that monosyllabic words are not as confusing as nonsense syllables. Nevertheless, monosyllabic words when presented at constant intensity levels do not truly represent realistic communication.

In comparison, the advantages of sentences over monosyllables and bisyllables are that they (i) offer additional insight regarding an individual's performance in more realistic communication scenarios; (ii) are considered to be valid indicators of intelligibility and give better representation of verbal communication [4]; (iii) elicit better accuracy and effectiveness in measuring speech reception thresholds (because sentence material results in a much steeper intelligibility function compared to tests using single words [7]); (iv) contain contextual cues and are expected to have better predictive validity compared to words; (v) help in assessment of co-articulation as well as temporal aspects of speech; and (vi) have face validity as 'natural' and 'meaningful' stimuli for assessing auditory function [8].

Over the years, different forms of sentence tests have been developed, keeping in mind the perceptual difficulties of those with hearing loss [9] and the language of the individual [10]. One of the first sentence tests to receive widespread clinical acceptance was the Central Institute of Deaf (CID) 'everyday sentences test' in English developed by Silverman and Hirsh [11]. The CID test uses a target-word format, i.e., although the subject must repeat the entire sentence during testing, scoring is based on correct recognition of key words.

It has been reported that the mother tongue of an individual affects his or her perception of speech and that participants consistently have better discrimination scores in their mother tongue compared to other languages [10]. Hence, it is important to have speech material in the mother tongue of an individual. In the German language, a sentence test was developed by Kollmeier and Wesselkamp [7]. It consists of 20 test lists with 10 sentences that are each phonemically balanced. The construction of these 20 lists comprised various steps. The first was a pilot study to arrive at a SNR yielding $50 \%$ correct identification of key words in 324 sentences. These 324 were then grouped into six groups, each group having sentences with similar intelligibility based on the results of the pilot study. Speech intelligibility measurements were again carried out on these six groups of sentences and a two-point discrimination function was derived. Based on the derived discrimination function, 20 phonemically balanced sentence lists were then formed from those sentences. Performance intensity discrimination functions calculated for these final 20 lists revealed that $50 \%$ sentences scores could be obtained at a SNR of $-6.1 \mathrm{~dB}$.
This test has been found to have several clinical applications, such as assessment of binaural interaction in individuals with normal hearing sensitivity and hearing impairment, assessment of benefits of binaural hearing aids [12], and monitoring the progress with training of children with cochlear implants.

India is a multilingual country. The All India Institute of Speech and Hearing (AIISH) is situated in Karnataka, a state in South India where Kannada is the official language. AIISH provides clinical services to individuals with communication disorders such as assessment of hearing sensitivity, fitting of various hearing devices, and rehabilitation of individuals with hearing impairment. A battery of test is administered for assessment, fitting of devices, and monitoring the progress of management. Speech identification tests are important tools in the test battery for the assessment of hearing and comparing the performance of hearing devices and/or settings [1].

The majority of service seekers visiting AIISH speak Kannada. This necessitates the development of a sentence test in the Kannada language for assessment of hearing and hearing device fitting.

Apart from clinical services, research studies also mandate the use of sentence lists. Improvements in hearing aid technology have increased the number of hearing aid parameters. In order to avoid a practice effect, the assessment of the effect of each parameter/algorithm requires a large number of sentence lists [13]. A QuickSIN (speech in noise) test in Kannada has been developed by Avinash et al. [14]. From a pool of 60 sentences and after familiarity rating, they constructed 12 lists with seven sentences each. The noise used was eight-talker speech babble. Hence, this test has a limited number of sentence lists (seven equivalent lists of seven sentences each). Further, this test has some sentences which occur more than once, giving rise to a possible practice effect.

Everyday communication demands that listeners understand speech in varying degrees of noise. It has been proven that, under similar circumstances, listeners with sensorineural hearing loss (SNHL) have a greater degree of difficulty in understanding speech in noise than do listeners with normal hearing [15]; also, when presented under quiet conditions, speech intelligibility measures are inherently limited by ceiling effects. Hence, this study aims to develop a large set of sentence lists which will i) achieve sentence as well as list equivalency in the presence of noise; and ii) provide normative value for the developed lists.

\section{Material and methods}

The study was carried out in two phases. Phase I consisted of the development of sentence lists in the Kannada language and phase II included standardisation of the material. All the conditions which required audio presentation of the stimuli were conducted in a sound-treated audiometric room. Informed consent was obtained from all the participants prior to testing. A detailed case history was taken and pure tone audiometry, speech audiometry, and immittance evaluation were carried out on all participants. All the participants had normal hearing sensitivity and 


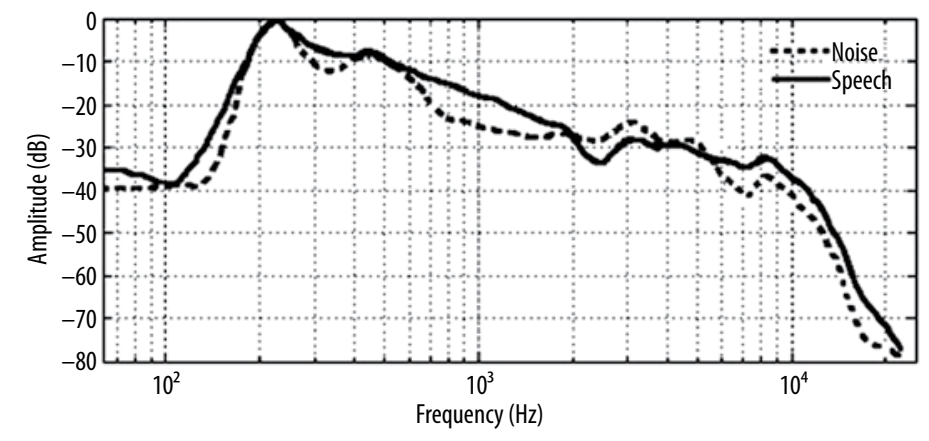

Figure 1. Long-term average speech spectrum (LTASS) of the developed sentences in Kannada language (solid line) and LTASS of spectrally shaped noise (dotted line)

normal middle ear function. Normal hearing sensitivity was defined as pure tone air-conduction thresholds within $15 \mathrm{~dB} \mathrm{HL}$ across $250 \mathrm{~Hz}$ to $8000 \mathrm{~Hz}$ in both ears and bone conduction thresholds within $15 \mathrm{~dB}$ HL across 250 $\mathrm{Hz}$ to $4000 \mathrm{~Hz}$ [16]. The SRT and SIS were referenced to the PTA. Further, the participants had 'A' type tympanograms and had ipsilateral and contralateral acoustic reflexes less than $100 \mathrm{~dB} \mathrm{HL}$ at $500 \mathrm{~Hz}, 1 \mathrm{kHz}$, and $2 \mathrm{kHz}$ [17].

\section{Phase I: Development of sentence lists in Kannada}

This phase involved selection of sentences, recording and editing, and assessment of sentence equivalency.

\section{Selection of sentences}

The sentences were selected from a large database. The sources were mainly major Kannada newspapers and magazines and day-to-day conversations. A sentence was chosen if a) the total number of words ranged from four to six; b) the number of syllables was between 14 and 16; c) it contained familiar and equally difficult words; d) it did not contain punctuation marks; e) it represented conversational speech; f) it did not contain proverbs, exclamations, proper names, or questions; g) it was complete (i.e., contained a verb) and was syntactically and grammatically correct; and h) it had semantically neutral content.

A total of 700 sentences were selected based on the above criteria. The mean length of the sentences was 4 or 5 words. For each of these sentences, four key words were identified by 10 native speakers of Kannada. The key words were defined as those words which were deemed to be important for comprehension of the sentence. If a sentence had only four words, all the words were considered as key words. They also rated the naturalness of the sentences on a five-point rating scale ( $5=$ natural and $1=$ artificial). Any sentence that received a mean rating of less than four was removed.

The predictability of words in sentences was also assessed by the same 10 participants. The predictable sentences were those which had key words that could be guessed from a single word or the whole sentence could be inferred from the context. The participants were presented sentences missing the target word and asked to guess the possible words that might occur. If the number of words guessed were more than two, then those sentences were considered to be less predictable [18] and hence were included in the list. This was done for all the key words in the sentence, a procedure which rules out contamination by highly predictable sentences, as these may elevate intelligibility scores compared to sentences with low predictability [19-22]. A total of 564 sentences were selected based on the familiarity and predictability ratings.

\section{Recording, editing, and noise mixing}

A single female speaker was selected from a group of three native speakers by five adult listeners, based on their subjective judgment regarding the speaker's ability to sustain constant vocal effort, maintain clear articulation, and provide neutral intonation. Audio recordings of 564 sentences were made in a sound-treated room, using a Shure SM48 cardioid dynamic microphone placed in front of the speaker at a distance of $0.5 \mathrm{~m}$ and a personal computer with Computerized Speech Lab (CSL) software, which also allowed amplitude monitoring. The waveforms were digitised with a 16bit A/D converter at a sampling frequency of $44,100 \mathrm{~Hz}$. The digitised waveforms were then edited using Adobe Audition (v 3.0) software to eliminate silent intervals at the beginning and end of each waveform. Other unwanted sounds, such as breathing noise and lip smacks, were also removed.

These 564 sentences were concatenated and spectrally analysed to derive its long term average speech spectrum (LTASS). The LTASS was then used to design an infinite impulse response (IIR) filter in MATLAB software (v 7.12). White noise was then subjected to the designed IIR filter parameters. Figure 1 illustrates the LTASS of speech and of the spectral shaped noise.

All the 564 sentences were then mixed with the generated spectrally shaped noise at each SNR level from $-7 \mathrm{~dB}$ SNR to $0 \mathrm{~dB}$ SNR, in $1 \mathrm{~dB}$ steps. This was achieved using a program written in MATLAB. This program calculates the RMS amplitude of the speech and noise signals in 50 millisecond bins and mixes them both at the specified signal-to-noise ratio.

\section{Determination of global SNR}

Speech intelligibility measures are inherently limited by floor and ceiling effects. To overcome these limitations associated with tests presented at a fixed level, adaptive procedures were used [23]. Adaptive procedures can be used to arrive at a global SNR. The global SNR is defined as the SNR which yields an average total intelligibility score of $50 \%$ [7]. The important advantage of determining and using a global SNR 
is minimisation of ceiling and floor effects. To obtain this, a pilot study was carried out using the following method.

A total of eight native Kannada-speaking male and female listeners (four males and four females) participated. Their ages ranged from 18 to 35 years (mean age of 26.2 years, $\mathrm{SD}=4.9$ ).

All the 564 sentences were delivered monaurally at the pre-recorded SNRs (from $-7 \mathrm{~dB}$ SNR to $0 \mathrm{~dB}$ SNR, in 1 $\mathrm{dB}$ steps, making a total of $8 \mathrm{SNRs}$ ) to a randomly chosen ear. Each participant was presented with 564 sentences at each SNR at their most comfortable level. The number of correctly identified words in each sentence was noted. The results of the pilot study revealed scores of approximately $50 \%$ correct at $-5 \mathrm{~dB}$ SNR. Hence, $-5 \mathrm{~dB}$ SNR was chosen as the global SNR.

\section{Assessment of sentence equivalency}

In order to arrive at sentences that were similar to each other, an initial process of sentence equivalency was carried out. The aim of this procedure was to eliminate sentences that were too easy or too difficult. The reasons for carrying out the equivalency assessments are as follows:

a) Though the sentences had equal RMS amplitudes, their intelligibility exhibited in the presence of spectrally shaped noise would not essentially be equal.

b) Factors such as the phonemes used, familiarity of words, as well as intonation and intensity variations, influence speech perception in noise [23].

A total of 15 native Kannada-speaking listeners (nine males and six female) were chosen for assessment of sentence equivalency. Their age ranged from 18 to 48 years with a mean age of 25.8 years $(S D=9.1)$.

Sentence equivalency was assessed at three SNRs: $-5 \mathrm{~dB}$ (which was found to be the global SNR) and two SNRs on either side of the global SNR, $-3 \mathrm{~dB}$ and $-7 \mathrm{~dB}$. These latter two SNRs $(-3 \mathrm{~dB}$ and $-7 \mathrm{~dB})$ were chosen to give values near the ceiling and floor of the sigmoid curve respectively. The 564 sentences were presented at $-3 \mathrm{~dB}$ SNR on five listeners, $-5 \mathrm{~dB}$ SNR on a separate group of five listeners, and $-7 \mathrm{~dB}$ SNR on a third group of five listeners. The stimuli were presented monaurally at the listener's most comfortable level. The sentences were played through a personal computer, connected to a calibrated audiometer, and delivered through Sennheiser HDA 200 closed dynamic headphones.

The participants were asked to repeat the sentences as accurately as possible and the responses were recorded on a printed sheet. The tester scored the responses. Each sentence was scored based on the number of key words correctly repeated, wherein contractions, spelled out contractions, identifiable mispronounced words, and changes in plurality were counted as correct. The maximum number of key words possible for each sentence was four. A score of 1 was given to each correctly identified key word. Incorrect and partially correct key words were given a score of 0 . The total number of correctly identified key words for each of the three sets was calculated. A second rater also verified the accuracy of the responses.
The mean values of correctly identified key words at $-3,-5$, and $-7 \mathrm{~dB}$ were obtained. The number of correctly identified key words for each sentence was compared with this mean. Sentences with scores above or below the mean were eliminated. Following this process, a total of 316 sentences of equivalent difficulty were shortlisted and included in the final lists. A total of 30 sentence lists, with 10 sentences each, were prepared such that they were phonemically balanced. The remaining 16 sentences were used as practice items. Phonemic balancing was done to make sure that each list was capable of yielding results representative of the subject's ability in language comprehension. The sentences in each list were phonemically balanced as close as possible using the frequency of occurrence of the phonemes in the Kannada language [24]. In total, 30 tentative lists of 10 sentences each were prepared and each list was optimised based on phonemic balance. This was done by finding out the frequency of occurrence of different phonemes of the key words in the sentences and matching this to their frequency of occurrence in Kannada given by Ramakrishna et al. [24].

\section{Phase II: Standardisation of sentence lists}

The sentence lists were standardised over a group of participants with normal hearing, so as to determine the normative performance, repeatability, and reliability of these sentence lists.

\section{Participants}

This phase involved 100 participants (59 males and $41 \mathrm{fe-}$ males) with hearing thresholds $\leq 15 \mathrm{~dB}$ HL. The age of the participants ranged from 18 to 55 years (with a mean of 29.4 years, $\mathrm{SD}=9.2$ ). The participants were tested in a sound-treated room. Normal hearing sensitivity and normal middle ear function were confirmed by the routine clinical audiometric test battery.

\section{Procedure}

The 30 lists with 10 sentences each were presented to a new group of 100 participants with normal hearing at -5 $\mathrm{dB}$ SNR (to avoid a ceiling effect) at their most comfortable level. The stimuli were presented monaurally (right and left ears chosen randomly). The sentences were played from a personal computer through the calibrated audiometer in a sound-treated audiometric room. The sentences were delivered through calibrated Sennheiser HDA 200 closed dynamic headphones.

The participants were instructed to repeat the sentences they heard. Prior to the actual testing, practice sentences (sentences not included in the lists) were presented. Each sentence was scored based on the number of key words identified and the scores were subjected to repeated measures ANOVA.

\section{Results}

Phase 1: Development of sentence lists in Kannada

The first phase of the study focused on the development of the sentence material in Kannada. This involved selection and determination of naturalness and predictability 


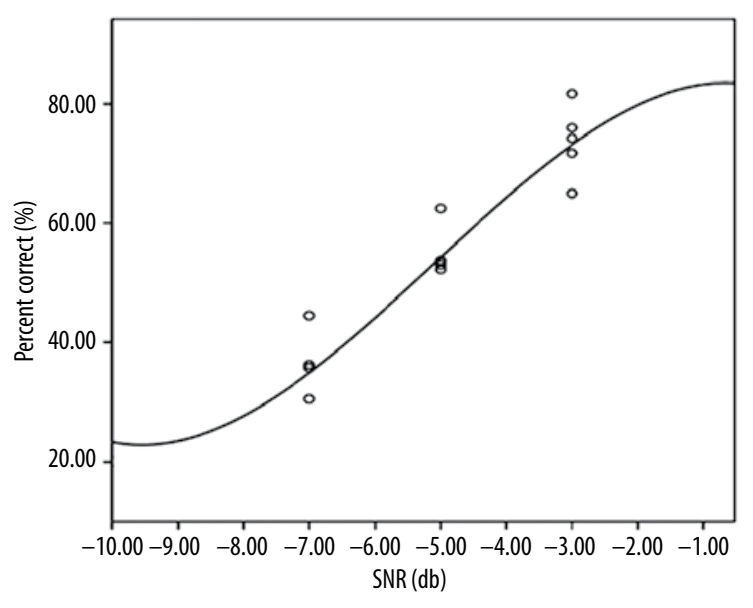

Figure 2. Sigmoidal function representing mean percent correct keyword identification at $-7 \mathrm{~dB}$ SNR, -5 $\mathrm{dB}$ SNR, and $-3 \mathrm{~dB}$ SNR. Each circle represents one participant

of 700 sentences, and determination of sentence equivalency of the 564 shortlisted sentences.

The results of the assessment of sentence equivalency revealed scores of approximately $75 \%$ correct (mean raw score $=2.95, \mathrm{SD}=1.2$, range $=0-4)$ at $-3 \mathrm{~dB} S N R, 50 \%$ correct (mean raw score $=2.19, \mathrm{SD}=1.1$, range $=0-4$ ) at $-5 \mathrm{~dB}$ $\mathrm{SNR}$, and $30 \%$ correct (mean raw score $=1.20, \mathrm{SD}=1.4$, range $=0-4$ ) at $-7 \mathrm{~dB}$ SNR. A sigmoidal function was obtained by plotting the identification scores (averaged for all 564 sentences at each SNR) against the SNRs. Figure 2 illustrates the percentage of correctly identified key words at the three SNRs for all individuals. The sentences which were too easy (145) and too difficult (103), a total of 248, were eliminated. A sentence was considered easy if the number of correctly identified key words was more than the mean scores obtained at those three SNRs, and a sentence was considered difficult if the number of correctly identified key words was less than the mean score obtained at those three SNRs. Thus based on this, 316 out of 564 sentences with moderate difficulty were considered for constructing the sentence lists.

The aim of the study was to construct 30 lists of 10 sentences each. Hence, only 300 of the 316 sentences were utilised to construct 30 lists, with 10 sentences each. All the 30 sentence lists contained all the speech sounds of the language. Of these, 25 lists could be phonemically balanced, i.e., the frequency of occurrence of speech sounds resembled the frequency of occurrence reported by Ramakrishna et al. [24]. The remaining 16 of the 316 sentences, not included in the sentence lists, were used for familiarisation.

\section{Phase II: Standardisation of sentence lists}

Normative performance was established on 100 participants with normal hearing at $-5 \mathrm{~dB}$ SNR. Table 1 illustrates the mean number of correctly repeated key word scores and standard deviation (SD) for each of the 30 lists.

It can be observed from Table 1 that the performance was quite uniform across the lists, except for List 1 and List 30 . To statistically determine if the difficulty level across lists was equivalent, the difference between the mean score of each listener and the score obtained by each individual for each list was calculated. Figure 3 presents the mean and SD of these modified scores. Repeated measures ANOVA was carried out on these data to determine if performance across lists varied significantly at the global SNR of $-5 \mathrm{~dB}$ SNR.

It can be observed in Figure 3 that the deviation from the average mean score for all the lists showed similar values, except for Lists $1,3,15,16$, and 30 . It can also be seen that the SD was higher for List 30 . The repeated measures ANOVA revealed that there was a significant difference in performance across the lists $[F(27.0,2.87)=2.29, p<0.001]$ revealing a main effect of lists. Hence, a Bonferroni pairwise comparison was done to determine the lists that differed in scores. The results of the post hoc analysis are given in Table 2 . The results revealed that List 1 was significantly different from Lists 3,15, and 16, and List 30 was significantly different from Lists 15 and 16 .

Table 1. Mean and SD of number of correctly identified key words for 30 lists $(n=100)$

\begin{tabular}{ccccccccc}
\hline & Mean & SD & & Mean & SD & & Mean & SD \\
\hline List 1 & 19.79 & 3.74 & List 11 & 21.47 & 3.47 & List 21 & 21.52 & 3.12 \\
\hline List 2 & 20.69 & 3.35 & List 12 & 20.74 & 3.50 & List 22 & 21.87 & 3.73 \\
\hline List 3 & 21.20 & 3.28 & List 13 & 20.72 & 3.29 & List 23 & 22.78 & 3.66 \\
\hline List 4 & 20.72 & 3.69 & List 14 & 21.46 & 3.72 & List 24 & 21.83 & 3.53 \\
\hline List 5 & 21.64 & 3.32 & List 15 & 21.57 & 2.30 & List 25 & 21.30 & 3.87 \\
\hline List 6 & 22.18 & 3.49 & List 16 & 21.44 & 3.39 & List 26 & 22.20 & 3.33 \\
\hline List 7 & 20.75 & 3.77 & List 17 & 21.14 & 3.49 & List 27 & 22.90 & 3.77 \\
\hline List 8 & 21.61 & 3.25 & List 18 & 22.11 & 3.24 & List 28 & 22.58 & 3.36 \\
\hline List 9 & 21.40 & 3.45 & List 19 & 22.47 & 3.04 & List 29 & 22.04 & 3.46 \\
\hline List 10 & 20.44 & 3.37 & List 20 & 21.51 & 3.54 & List 30 & 23.70 & 3.73 \\
\hline
\end{tabular}




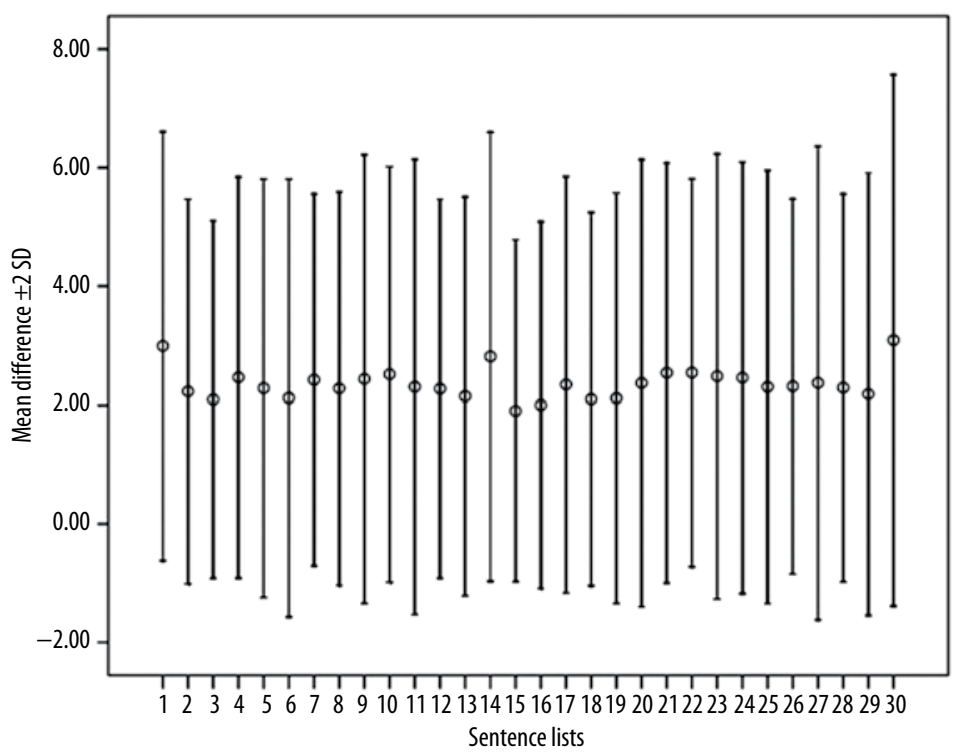

Figure 3. Mean difference and SD for 30 lists. Mean difference is the difference between the mean score of each listener and the score obtained by each individual for each list. For each list, $n=100$; error bars show \pm 2 standard deviations from the mean

Table 2. Results of pair-wise comparison of lists using Bonferroni post hoc analysis

\begin{tabular}{ccccc}
\hline $\begin{array}{c}\text { Groups } \\
(\mathbf{I})\end{array}$ & $\begin{array}{c}\text { Groups } \\
(\mathbf{J})\end{array}$ & $\begin{array}{c}\text { Mean difference } \\
(\mathbf{I}-\mathbf{J})\end{array}$ & $\begin{array}{c}\text { Standard } \\
\text { error }\end{array}$ & Significance \\
\hline \multirow{2}{*}{ List 1 } & List 3 & $0.899^{\star}$ & .212 & .022 \\
\cline { 2 - 5 } & List 15 & $1.087^{\star}$ & .251 & .015 \\
\hline List 15 & List 16 & $0.992^{\star *}$ & .221 & .009 \\
\hline List 16 & List 30 & $1.185^{\star \star}$ & .261 & .007 \\
\hline
\end{tabular}

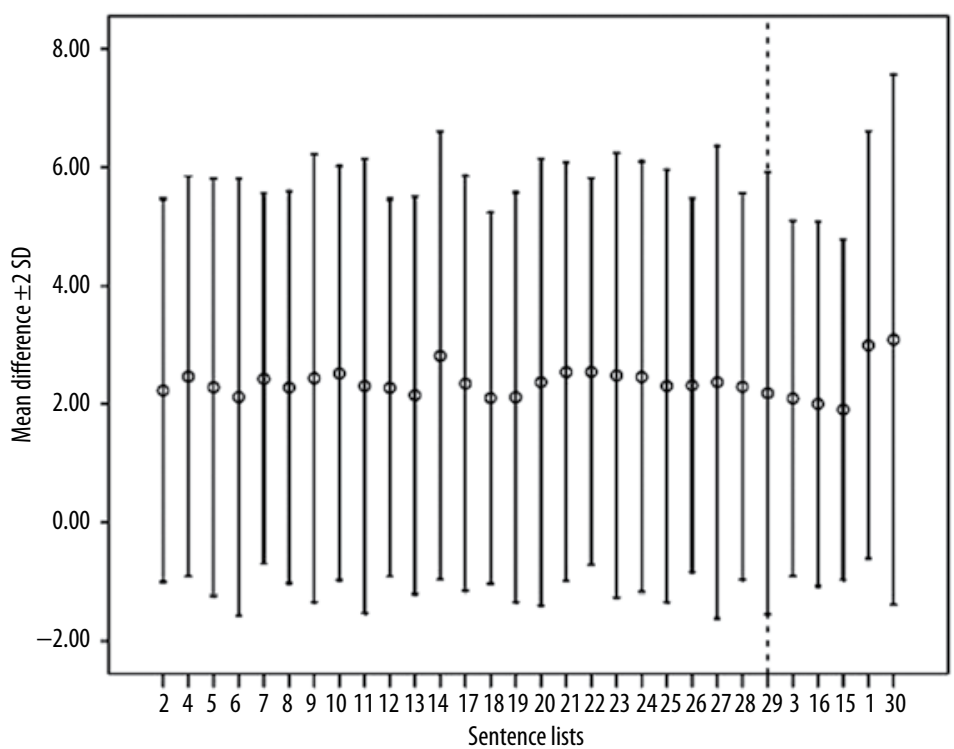

Figure 4. Mean difference and SD for the 30 lists, as for Fig. 3, but in revised order. The lists with significantly different scores are shown to the right of the dotted line

Figure 4 illustrates the mean and SD for all the 30 lists, but in a different order, i.e., Lists $1,3,15,16$, and 30 are included at the end. The order of these five lists depends on their MD. The lists at and below the reference line are the equivalent lists. In the final sentence test, Lists 3,16 , 15,1 , and 30 are renumbered as Lists $26,27,28,29$, and 30 , respectively. The equivalent lists are given from List 1 to 25 and the key words are highlighted. 
Of these 30 lists, the first 21 lists were completely phonemically balanced and the remaining five lists include all the phonemes in the language; however, complete phonemic balancing could not be achieved in them. After removing Lists $1,3,15,16$, and 30 , the overall normative performance for the 100 participants with normal hearing had a mean SIS of $54 \%$ at $-5 \mathrm{~dB}$ SNR.

\section{Discussion}

The study involved selection of sentences in Kannada, determination of naturalness and predictability of sentences, determination of sentence equivalency, formation of sentence lists, and standardisation of sentence lists.

Assessment of sentence equivalency gave scores of approximately $75 \%$ correct at $-3 \mathrm{~dB}$ SNR, $50 \%$ correct at $-5 \mathrm{~dB}$ SNR, and $30 \%$ correct at $-7 \mathrm{~dB}$ SNR. These results are in agreement with those obtained by Kollmiere and Wesselkemp [7] who obtained $20 \%$ correct scores at $-8 \mathrm{~dB}$ SNR and $80 \%$ correct scores at $-4 \mathrm{~dB}$ SNR for sentence lists. Hence, the sentences in the present study also have a sigmoidal function as reported in the literature.

Any test material should have equivalent lists in terms of number of syllables, words, sentences, and perceptual difficulty. A total of 30 lists were constructed in the present test using the equivalent sentences, with a similar of number of syllables across the lists. Each list had 10 sentences. The assessment of list equivalency resulted in the removal of Lists 1, 3, 15, 16, and 30. After removing these five lists, overall normative performance for the 100 participants with normal hearing had a mean SIS of $54 \%$ at -5 dB SNR. Kollmeier and Wesselkemp [7] reported a SNR of $-6.1 \mathrm{~dB}$ for $50 \%$ scores. Although the results of this study are comparable with those reported by Kollmeier and Wesselkemp, this small difference could be because of differences in the methods. To generate homogeneity, Kollmeier and Wesselkemp applied weighting factors depending on the level of difficulty of the words. They reported that if the weighing factor was removed, variations in the scores of up to $4 \%$ occurred. In addition, in their study the material was spoken by a male talker.

Further, the standard deviation of the raw scores, given in Table 1, is lower than that reported by Kollmeier and Wesselkemp [7]. This suggests that there is a high homogeneity of the sentence lists in the present study even in the difficult condition of $-5 \mathrm{~dB}$ SNR. In addition, the sigmoidal function for sentences used in the lists was derived using the scores at $-3,-5$, and $-7 \mathrm{~dB}$ SNRs. The test developed by Kollmeier and Wesselkemp [7] has been found to have clinical applications in assessment, comparing hearing aid benefits, and monitoring progress with training. Thus, it is suggested that the sentences in the present study could also be used in conditions of varying difficulty (in terms of SNR) for routine hearing evaluation, hearing device fitment, and monitoring progress in rehabilitation. The sentence lists have been found to have application in selecting hearing aid settings for different languages by Nisha and Manjula [25]. Validation of the sentence lists is being carried out for hearing evaluation on a clinical population.

Of the final 25 lists, 21 were completely phonemically balanced and the remaining four included all the phonemes in the language; however, complete phonemic balancing could not be achieved. Despite this difference, the identification scores are equivalent for all 25 lists. This implies that phonemic balancing is not a major factor in bringing about variations in identification scores. These results concur with those reported by Martin et al. [26].

\section{Conclusions}

The Kannada sentence identification test consists of 25 lists with 40 key words each. Though the normative value for the sentence lists has been established at $-5 \mathrm{~dB}$ SNR, a sigmoidal function was derived for all the sentences in the lists at $-3,-5$, and $-7 \mathrm{~dB}$ SNRs. Thus, it can be assumed that the 25 sentence lists are equivalent at different SNRs. The usefulness of this tool needs to be evaluated in various applications such as comparing different parameters of hearing devices and monitoring rehabilitation.

\section{Acknowledgements}

This data is a part of a project funded by the AIISH Research Fund. The authors extend their thanks to all the participants. We are also grateful to Dr Vasanthalakshmi, Lecturer in Biostatistics for extending help in statistics and to Dr Ramadevi, Audiologist Grade I, All India Institute of Speech and Hearing, Mysore, for IPA transcription. AIISH holds the copyright for the sentence materials; readers may request the developed test from the Director, AIISH.

\section{Conflict of interests}

None.

\section{References:}

1. Mueller GH. Speech audiometry and hearing aid fittings: Going steady or casual acquaintances? Hear J, 2001: 54(10): 19-29.

2. Wilson RH, McArdle RA. Speech signals used to evaluate the functional status of the auditory system. J Rehab Res Dev 2005; 42(Suppl. 2): 79-94.

3. Taylor B. Speech-in-noise tests: How and why to include them in your basic test battery. Hear J, 2003; 56: 40-46.

4. Tyler R. The use of speech-perception tests in audiological rehabilitation: Current and future research needs. J Acad Rehab Audiol, 1994; 27: 47-56.
5. Hirsh IJ. The measurement of hearing. McGraw-Hill: New York; 1952.

6. Carhart R. Problems in the measurement of speech discrimination. Arch Otolaryngol, 1965; 82 (9): 253-60.

7. Kollmeier B, Wesselkamp M. Development and evaluation of a German sentence test for objective and subjective speech intelligibility assessment. J Acoust Soc Am, 1997; 102(4): 2412-21.

8. Miller GA, Heise GA, Lichten W. The intelligibility of speech as a function of the context of the test materials. J Experimental Psychol, 1951; 41(5): 329-35. 
9. Mendel LL, Danhauer JL. Audiologic evaluation and management and speech perception assessment. San Diego: Singular Publishing Group; 1997.

10. Delattre P. Comparing the vocalic features of English, German, Spanish and French. Int Rev Appl Linguist, 1964; 2: 71-98.

11. Silverman SF, Hirsh IJ. Problems related to the use of speech in clinical audiometry. Ann Oto Rhinol Laryngol, 1955; 64: 1234.

12. Peissig J, Kollmeier B. Directivity of binaural noise reduction in spatial multiple-noise-source arrangements for normal and impaired listeners. J Acoust Soc Am, 1997; 101: 1660-70.

13. Gatehouse $S$. The time course and magnitude of perceptual acclimatization to frequency responses: Evidence from monaural fitting of hearing aids. J Acoust Soc Am, 1992; 92: 1258-68.

14. Avinash MC, Meti RR, Kumar AU. Development of sentences for quick speech-in-noise (QuickSin) test in Kannada. J In Sp Hear Assoc, 2010; 24(1): 59-65.

15. Dubno JR, Dirks DD, Morgan DE. Effect of mild hearing loss on speech recognition in noise. J Acoust Soc Am, 1984; 76: 87-96.

16. Clark JG. Uses and abuses of hearing loss classification. ASHA, 1981; 23: 493-500.

17. Gelfand SA. Hearing: An introduction to psychological and physiological acoustics. 3rd ed. New York: Marcel Dekker; 1998.
18. Rahana NVV, Yathiraj A. Development of high and low predictable English sentence test. Unpublished Master's Dissertation. Mysore: University of Mysore; 2007.

19. McGarr NS. The effect of context on the intelligibility of hearing and deaf children's speech. Lang Speech, 1981; 24: 255-64.

20. Garcia J, Cannito M. Influence of verbal and nonverbal contexts on the sentence intelligibility of a speaker with dysarthria. J Speech Hear Res, 1996; 39: 750-60.

21. Garcia J, Dagenais P. Dysarthric sentence intelligibility: Contribution of iconic gestures and message predictiveness J Speech Hear Res, 1998; 41(6): 1282-93.

22. Barreto S, Ortiz KZ. Intelligibility: effects of transcription analysis and speech stimulus. Pro Fono, 2010; 22(2): 125-32.

23. Nilsson M, Soli SD, Sullivan JA. Development of the hearing in noise test for the measurement of speech reception thresholds in quiet and in noise. J Acoust Soc Am, 1994; 95(2): 1085-99.

24. Ramakrishna BS, Nair KK, Chiplunkar VN, Atal BS, Ramachandran V, Subramanian R. Some aspects of the relative efficiencies of Indian languages. Ranchi, India: Catholic Press; 1962.

25. Nisha KV, Manjula P. Are different hearing settings required for different languages? Unpublished Master's Dissertation. Mysore: University of Mysore; 2013.

26. Martin FN, Champlin CA, Perez DD. The question of phonetic balance in word recognition testing. J Am Acad Audiol, 2000; 9: 95-104 